\title{
DIETHYL STILBCESTROL AS A COMPETITIVE INTRACELLULAR HYDROGEN CARRIER
}

\author{
By R. M. HOCHSTER and PROF. J. H. QUASTEL, F.R.S. \\ Montreal General Hospital Research Institute, Montreal
}

$S^{T}$ TILBESTROL has found varied use in the last decade in the field of hormone therapy, being a synthetic oestrygen of high potency. It appears to affect cellular growth processes as shown by $(a)$ the production of mammary carcinoma of the mouse and testicular tumours in 'Strong A' strain mice, $(b)$ its ability to cause regression of human and animal prostatic cancer and human breast tumour.

It is conceivable that a substance thus capable of modifying normal cellular growth might produce its effect by altering some of the enzymatic processes of the cell. Indeed, MeShan and Meyer ${ }^{1}$ showed that stilbœstrol inhibits the succinoxidase system in liver and pituitary tissues of the rat. In a later paper, McShan, Meyer and Erway ${ }^{2}$ showed that the succinoxidase system of other tissues is also inhibited and that a number of substances produce the same effect so long as they possess two phenolic groups in their structure (for example, benzœstrol, hydroquinone). Substances containing alcoholic in place of phenolic groups were found ineffective.

Case and Dickens ${ }^{3}$ investigated stilbcestrol as a possible inhibitor of cytochrome oxidase. They found that $4: 4^{\prime}$-dihydroxystilbene, which powerfully inhibits the succinoxidase system, does not inhibit cytochrome oxidase or succinic dehydrogenase per se. Gordan and Elliott ${ }^{4}$, studying stilbœstrol inhibition of glucose oxidation, also showed that cytochrome oxidase is not the point of attack with rat cerebral cortex homogenates.

We have now found that stilbostrol will act as a hydrogen carrier in some biological oxidations and may compete with other hydrogen carriers in the cell. In this way it can, in certain circumstances, act as a respiratory catalyst ; in other circumstances it may appear as a respiratory poison.

This communication represents a preliminary account of these findings, which will be deseribed in detail elsewhere.

We have made use of the fact that a suspension of freshly prepared manganese dioxide proves to be an excellent hydrogen acceptor suitable for investigations of biological respiratory systems under anaerobic conditions. Manganese dioxide was first used for this purpose by Mann and Quastel ${ }^{5}$ in their studies of manganese metabolism in soil. Experiments are carried out with the Warburg manometric apparatus in an atmosphere of 93 per cent nitrogen +7 per cent carbon dioxide at $27^{\circ} \mathrm{C}$., using a medium containing $0.025 \mathrm{M}$ sodium bicarbonate solution. The following reactions take place, $R \mathrm{H}_{2}$ representing the substance oxidized :

$$
\begin{gathered}
R \mathrm{H}_{2}+\mathrm{MnO}_{2}=\mathrm{Mn}(\mathrm{OH})_{2}+R \\
\mathrm{Mn}(\mathrm{OH})_{2}+\mathrm{CO}_{2}=\mathrm{MnCO}_{3}+\mathrm{H}_{2} \mathrm{O} .
\end{gathered}
$$

The velocity of carbon dioxide uptake is a measure of the rate of $\mathrm{MnO}_{2}$ reduction by $R \mathrm{H}_{2}$. Both $\mathrm{MnO}_{2}$ and $\mathrm{MnCO}_{3}$ are almost insoluble in our experimental media and do not appear to affect the course of enzymic changes.

Using $\mathrm{MnO}_{2}$ as a terminal hydrogen acceptor, it is possible to show that stilboestrol is a hydrogen carrier for alcohol and lactic dehydrogenases of yeast and f or the amino-acid oxidase of rat kidney.

Stilbœstrol (I) is easily oxidized by $\mathrm{MnO}_{2}$ suspensions to the corresponding quinone (II) :<smiles>CCCCC(=C(CC)C(CC)=C1C=CC(=O)C=C1)C(CC)(CCC)c1ccc(O)cc1</smiles>

The rate of oxidation may be followed manometrically in a bicarbonate medium in an atmosphere of 93 per cent nitrogen +7 per cent carbon dioxide. Details of this reaction and of a variety of other oxidations accomplished by $\mathrm{MnO}_{2}$ will be published shortly.

\section{Experiments with Yeast Dehydrogenase Systems}

An acetone-dried powder of baker's yeast which had been prepared in the cold by crushing the cells in a shaker with glass beads in presence of 2.5 per cent nicotinamide solution in phosphate buffer $(p H \mathrm{H} \cdot 0)$, with subsequent precipitation of the cell-free extract by cold acetone, was found to be a suitable source of alcohol and lactic dehydrogenases. $1 \mathrm{ml}$. of an aqueous suspension of the powder $(55 \mathrm{mgm} . / \mathrm{ml}$.) was placed in the main compartment of a Warburg manometer vessel. To this was added $0.2 \mathrm{ml}$. of $\mathrm{MnO}_{2}$ suspension and $0.025 M$ sodium bicarbonate solution. $0.2 \mathrm{ml}$. of $0.1 M$ sodium lactate or ethyl alcohol was placed in the side arm of the manometer vessel and tipped in following the equilibration period.

Stilbœstrol was added in methyl alcohol solution to the medium in the main compartment of a Warburg vessel, a fine suspension of the stilbœstrol being produced. Methyl alcohol was added as a control to all vessels not containing stilbœstrol. It is oxidized to a slight extent by $\mathrm{MnO}_{2}$. In all stilbœstrol- $\mathrm{MnO}_{2}$ experiments a thermal equilibrium period of thirtyfive minutes was allowed to take place prior to tipping in the substrate, during which time the reaction between stilbcestrol and $\mathrm{MnO}_{2}$ to the corresponding quinone proceeded almost (91-93 per cent) to completion.

Typical results (Figs. 1 and 2) show the carrier effects of stilbœstrol. They are similar to those obtained when methylene blue is used as an alternative hydrogen carrier (Fig. 3). The lines designated by $B$ show the carrier effects of both stilbœstrol and methylene blue on the substrate already present in the yeast preparation without additional substrates.

\section{Experiments with Rat Kidney Amino-Acid Oxidase}

Kidney extracts were prepared by grinding, for 5 min., $3 \mathrm{gm}$. of fresh rat kidney tissue with 'Pyrex' glass in a mortar containing $5 \mathrm{ml}$. of cold saline. 


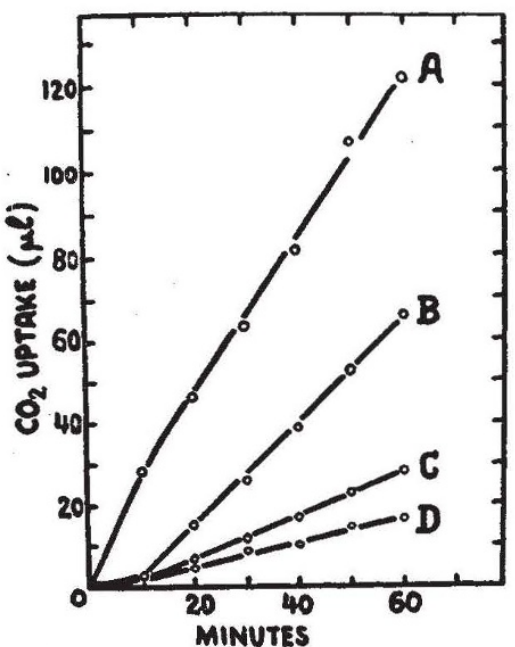

Fig. 1. Stilbcestrol as a carrier for alcohol dehydrogenase $A$, Yeast powder + methanol + ethanol + stilbœestrol ; $B$, yeas powder + methanol + stilbostrol ; $C$, methanol + stilbosstrol; $D$, yeast powder + methanol + ethanol. Concentrations used : stilbœstrol, $2 \cdot 3 \times 10^{-3} M$; ethanol, $6.0 \times 10^{-3} M$; methanol, $1 \cdot 55 \mathrm{M}$; yeast powder, $55 \mathrm{mgm}$. per vessel

Following $10 \mathrm{~min}$. standing at room temperature. another $2 \mathrm{ml}$. of saline were added and the mixture squeezed through moistened surgical muslin. $0 \cdot 2 \mathrm{ml}$. of $0.1 M d l-\alpha$-alanine was placed in the side arm of the manometer vessel containing the kidney preparation and $\mathrm{MnO}_{2}$ suspension in presence of bicarbonate. After equilibration and tipping in the amino-acid, it was found that stilbcestrol acts as an accelerator of the oxidation of alanine. Typical results are shown in Table 1.

There is little doubt that stilbostrol (I) acts through the formation of its corresponding quinone (II), a high concentration of which is provided by the action of $\mathrm{MnO}_{2}$ before addition of the substrate.

Stilbene quinone was prepared originally by Fieser ${ }^{6}$, using potassium molybdicyanide, and diethyl stilbœstrol quinone was made by $\mathrm{H}$. v. Euler and $\mathrm{E}$. Adler ${ }^{7}$, using lead tetra acetate. We prepared this quinone with $\mathrm{MnO}_{2}$, and although we, like v. Euler and Adler, were unable to obtain a crystalline product,

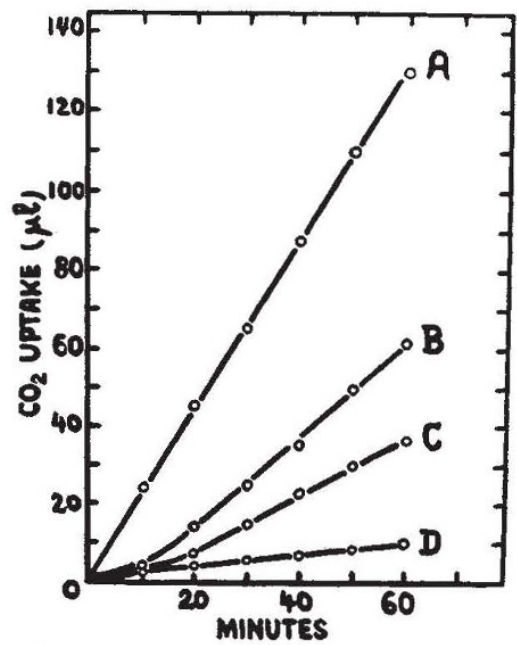

Fig. 2. Stilbœstrol as a carrier for lactic dehydrogenase. $A$, Yeast powder + methanol + sod. lactate + stilbcestrol; $B$, yeast powder + methanol + stilbœstrol; $C$, methanol + stilbœstrol ; $D$, yeast powder + methanol + sod. lactate. Concentrations as in Fig. 1 (lactate same as ethanol)
Table 1. Anaerobic oxidation of $d l-a$-alanine by a rat kidney extract

\begin{tabular}{|c|c|c|}
\hline \multirow{2}{*}{$\begin{array}{l}\text { Kidney extract, methyl alcohol, } \\
\mathrm{MnO}_{2}, \mathrm{NaHCO}_{3} \text {, together with: }\end{array}$} & \multicolumn{2}{|c|}{$\mu \mathrm{l} . \mathrm{CO}$, uptake at $27^{\circ} \mathrm{C}$. } \\
\hline & After $30 \mathrm{~min}$. & After $60 \mathrm{~min}$. \\
\hline $\begin{array}{l}\text { Nil } \\
\alpha \text {-Alanine } \\
\text { Stilbœstrol } \\
\alpha \text {-Alanine + stilbœstrol }\end{array}$ & $\begin{array}{r}14 \\
79 \\
25 \\
117\end{array}$ & $\begin{array}{r}32 \\
142 \\
58 \\
234\end{array}$ \\
\hline
\end{tabular}

Concentrations used: Kidney extract $325 \mathrm{mgm}$. tissue (wet wt.) per vessel, $d l$ - $\alpha$-alanine $6 \cdot 0 \times 10^{-3} M$, stilbostrol $2 \cdot 3 \times 10^{-3} M$, methyl

its physical properties agreed with those described by these authors.

Diethyl stilbœstrol quinone is doubtless the actual hydrogen acceptor in our in vitro systems where reduction to diethyl stilbœstrol by the dehydrogenase takes place with subsequent oxidation to the quinone by $\mathrm{MnO}_{2}$.

\section{Stilbœstrol as a Competitive Hydrogen Carrier}

After having established the carrier effect of stilbœstrol, it seemed to us that this substance, in producing the observed inhibitions of glucose oxidation in brain and the succinoxidase system of animal tissues ${ }^{\mathbf{1}, \mathbf{2}, \mathbf{8}}$, may effect its inhibition by competition with other, more active, hydrogen carriers rather than by an inhibition of any particular enzyme.

Lytochrome $c$ acts as a catalyst of the oxidation of lactate or of alcohol by $\mathrm{MnO}_{2}$ in presence of the appropriate dehydrogenases of acetone-dried yeast. The addition of stilbcestrol suppresses the catalytic effect of cytochrome $c$ on the lactic dehydrogenase system, but it has little or no effect on the alcohol dehydrogenase system. Typical results using the $\mathrm{MnO}_{2}$ technique in presence of nitrogen - carbon dioxide are shown in Table 2.

Table 2. Anaerobic oxidation of sodium lactate and ethyl alcohol by a yeast-cytochrome $c-\mathrm{MnO}_{2}$ system (Results expressed as $\mu \mathrm{l} . \mathrm{CO}_{2}$ uptake in $30 \mathrm{~min}$. at $27^{\circ} \mathrm{C}$.)

\begin{tabular}{|c|c|c|}
\hline \multirow{2}{*}{$\begin{array}{l}\text { Yeast powder, cytochrome } c \text {, } \\
\text { methyl alcohol, } \mathrm{NaHCO}, \\
\text { together with: }\end{array}$} & \multicolumn{2}{|c|}{ Substrate } \\
\hline & $\underset{\left(6.0 \times 10^{-3} M .\right)}{\text { Lactate }}$ & $\underset{\left(1 \cdot 2 \times 10^{-3} M_{.}\right)}{\text {Ethanol }}$ \\
\hline $\begin{array}{l}\text { Nil } \\
\text { Stilbœstrol } \\
\text { Substrate } \\
\text { Substrate + stilbcestrol }\end{array}$ & $\begin{array}{r}40 \\
68 \\
186 \\
90\end{array}$ & $\begin{array}{l}27 \\
40 \\
76 \\
95\end{array}$ \\
\hline
\end{tabular}

Concentrations used: cytochrome $c 7.2 \times 10^{-3} M$, yeast powder $55 \mathrm{mgm}$. per vessel; others as in Table 1

The same differential effect of stilbœstrol on the two dehydrogenase systems is observable when the experiments are carried out aerobically, the $\mathrm{MnO}_{2}$ being replaced by the cytochrome oxidase system (see Table 3). For experiment, a rat brain homogenate was added as a source of cytochrome oxidase to the yeast system. This was necessary as the acetone treatment of the yeast had destroyed most of its cytochrome oxidase. The homogenate was prepared with 0.9 per cent sodium chloride in an all-glass homogenizer ${ }^{8}$.

Without the addition of extra cytochrome $c$, stilbœstrol completely inhibits the oxidation of lactate, while in presence of added cytochrome $c$ this effect is not as great, due doubtless to the increased cytochrome concentration. Stilbostrol has apparently no effect on alcohol oxidation in this system. The results are shown in Table 3 . These results also show that stilbcestrol oxidation may be catalysed by the presence of cytochrome $c$.

Our findings confirm those of Case and Dickens ${ }^{3}$ in showing that cytochrome oxidase is not attacked by 


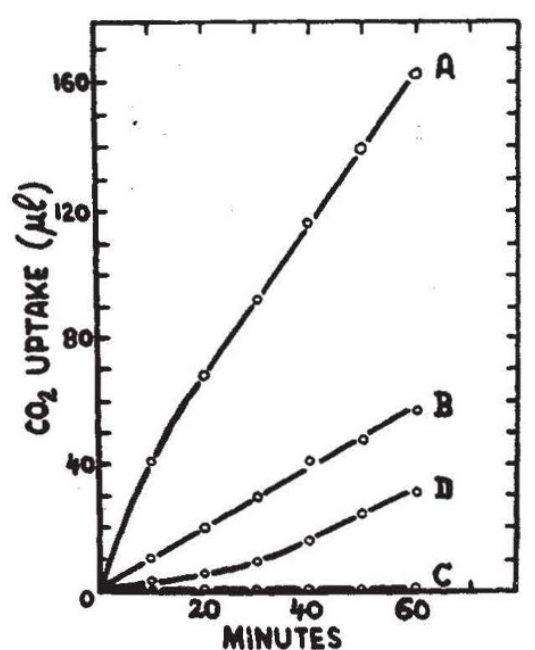

Fig. 3. Methylene blue as a carrier for alcohol dehydrogenase. $A$, Yeast powder + ethanol + methylene blue ; $B$, yeast powder + methylene blue ; $C$, methylene blue ; $D$, yeast powder + ethanol. Concentrations as in Fig. 1; methylene blue, $8.0 \times 10^{-5} \vec{M}$

stilbœestrol, since it has no effect on the alcohol dehydrogenase system studied aerobically. The results also show that stilbœstrol does not inhibit the cozymase-linked alcohol dehydrogenase.

Stilboestrol, however, while it catalyses the anaerobic oxidation of lactate by lactic dehydrogenase in presence of $\mathrm{MnO}_{2}$, strongly inhibits this oxidation when catalysed by cytochrome $c$. Since it is clear that stilbostrol does not inhibit yeast lactic dehydrogenase, for otherwise it could not catalyse its activity with $\mathrm{MnO}_{2}$, it follows that the stilbœestrol (or rather its quinone) must exert its effect by competing with cytochrome $c$ as a hydrogen acceptor for the lactic dehydrogenase. Stilbœstrol, as already mentioned, is converted quantitatively into its quinone by $\mathrm{MnO}_{2}$ and it is the quinone doubtless which competes with cytochrome $c$ for the enzyme.

The competition between stilbœstrol quinone and cytochrome $c$ cannot take place with all enzymes with which cytochrome $c$ is associated; otherwise cytochrome oxidase and cytochrome reduction by reduced flavoprotein would also be inhibited by stilbœstrol. This is not the case, as shown by the lack of effect on alcohol oxidation.

This phenomenon of an inhibition of a respiratory system by competition of a sluggish hydrogen acceptor with a more active one for the dehydro. genase involved has received confirmation by our finding that a series of hydrogen carriers may be employed in place of cytochrome $c$ in the $\mathrm{MnO}_{2}-$ lactic dehydrogenase system and that admixture of

Table 3. Aerobic oxidation of sodium lactate and ethyl alcohol by a mixed yeast-brain preparation

(Results expressed as $\mu$ l. oxygen uptake in $30 \mathrm{~min}$. at $27^{\circ} \mathrm{C}$.)

\begin{tabular}{|c|c|c|c|}
\hline \multirow[b]{3}{*}{$\begin{array}{l}\text { Yeast powder, rat brain } \\
\text { homogenate, nicotinamide, } \\
\text { methyl alcohol, with: }\end{array}$} & \multicolumn{3}{|c|}{ Substrate } \\
\hline & \multicolumn{2}{|c|}{ Lactate } & Ethanol \\
\hline & $\begin{array}{l}\text { No added } \\
\text { cyto- } \\
\text { chrome }\end{array}$ & $\begin{array}{c}\text { Added } \\
\text { cyto- } \\
\text { chrome } c\end{array}$ & $\begin{array}{c}\text { Added } \\
\text { cyto- } \\
\text { chrome } c\end{array}$ \\
\hline $\begin{array}{l}\text { Nil } \\
\text { Stilbøestrol }\left(2 \cdot 3 \times 10^{-3} M\right) \\
\text { Substrate }\left(1 \cdot 2 \times 10^{-2} M\right) \\
\text { Substrate + stilbøstrol }\end{array}$ & $\begin{array}{l}54 \\
14 \\
82 \\
17\end{array}$ & $\begin{array}{r}61 \\
58 \\
392 \\
190\end{array}$ & $\begin{array}{l}55 \\
65 \\
81 \\
94\end{array}$ \\
\hline
\end{tabular}

Concentrations used : cytochrome $\mathrm{c} 4.8 \times 10^{-5} \mathrm{M}$, rat brain $120 \mathrm{mgm}$ (wet wt.) per vessel, nicotinamide $1.3 \times 10^{-2} M$; others, see Table stilbœstrol brings about inhibitions of some carrier activities and not of others. Moreover, the effects are to be found with a variety of enzyme systems, including alcohol dehydrogenase, $\alpha$-glycerophosphate dehydrogenase and triosephosphate dehydrogenase. Details of these findings will, it is hoped, be published shortly.

\section{Competitive Hydrogen Carriers}

The phenomenon of competition of one hydrogen acceptor with another for a dehydrogenase, resulting in an inhibition of dehydrogenase activity, if the acceptor with the higher affinity for the enzyme is the more sluggish hydrogen carrier, must be one of general importance.

It makes it possible to understand how a molecule may inhibit or divert the course of intracellular oxidations without interference with the enzymes involved or without competition with the substrates activated by these enzymes. Clearly, therefore, the presence of such a competitive hydrogen carrier may markedly affect metabolism and cell growth. It is not unreasonable to suggest that the physiological and therapeutic effects of stilbœestrol may find an explanation in its behaviour as a competitive hydrogen carrier.

Our thanks are due to the Banting Research Foundation, Toronto, for support in the above investigation, to Dr. G. W. Holden of Charles E. Frosst and Co., Montreal, for having generously supplied the diethyl stilbostrol, and to Dr. K. A. C. Elliott for the cytochrome $c$ which we have used.

${ }^{2}$ MeShan, W. H., and Meyer, R. K., Arch. Biochem., 9, 165 (1946). "MeShan, W. H.. Meyer, R. K., and Erway, W. F., Arch. Biochem., $15,99(1947)$

${ }^{3}$ Case, E. M., and Dickens, F., Biochem. J., 43, 481 (1948).

4 Gordan, E. S., and Elliott, H. W., Endocrinol., 41, 517 (1947).

${ }^{5}$ Mann, P. J. G., and Quastel, J. H., Nature, 158, 154 (1946).

- Fieser, L. F., J. Amer. Chem. Soc., 52, 4915 (1930).

' Euler, H. von., and Adler, E., The Svedberg Memorial Volume, 246 (1944).

${ }^{8}$ Potter, V. R., and Elvehjem, C. A. J. Biol. Chem., 114, 495 (1936).

\section{CLASSIFICATION OF BACTERIA}

By E.J. FERGUSON WOOD

Marine Biolozical Laboratory, Commonwealth Scientific and Industyial Research Organisation, Cronulla, N.S.W.

THERE is a growing feeling of dissatisfaction annong bacteriologists with Bergey's "Manual"1 and its system of classification of the bacteria. The uncritical listing of 'species' and the construction of inadequate keys leads to the creation of more 'species' on no grounds other than that they do not fit the described 'species'. No study of the variation within or between species or genera is required, so, in the majority of cases, none is made. Cowan ${ }^{2}$ has suggested the abolition of priority, and recognition of only such forms as are preserved as type cultures. The difficulty here is that cultures tend to vary upon repeated sub. culture, some properties (for example, agar digestion, motility, luminescence) being lost very rapidly by some strains. This is especially the case with saprophytic forms and is probably not appreciated by those who work only with the more stable pathogenic types and their allies. Furthermore, few type culture collections will include these saprophytic forms.

The solution to the problem seems to lie in an alteration of the genus-species concept, a suggestion 